\title{
Pacific Rim Connections: Relinking the Vietnamese Apparel Industry to the Global Economy*
}

\author{
David A. Smitil And Angli NgOC Tran

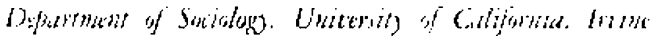

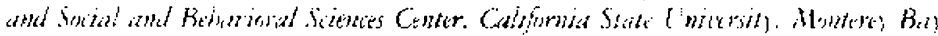

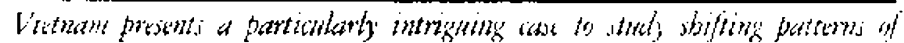

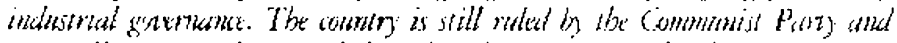

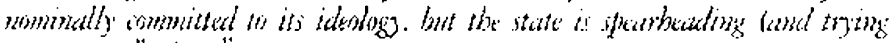

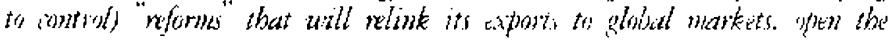

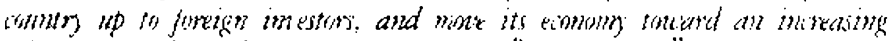

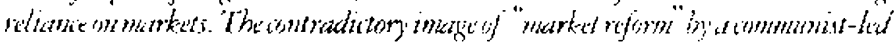

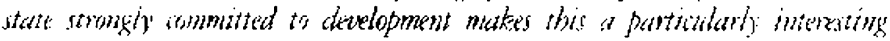

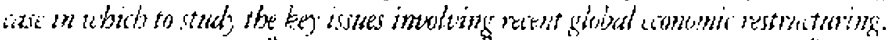

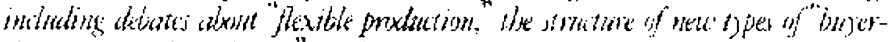

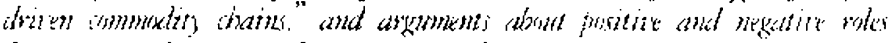

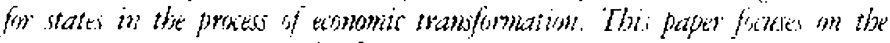

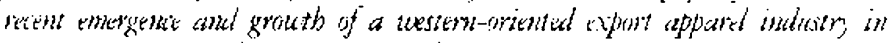

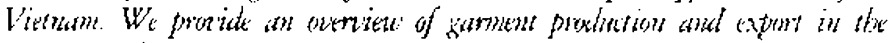
Astan Paific Rim. and sketch out the recem histon of the liktutmese textile

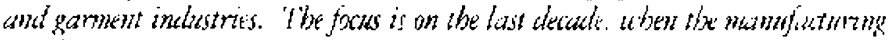

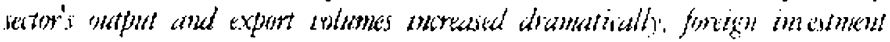

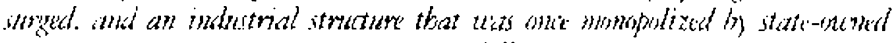

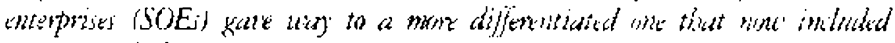

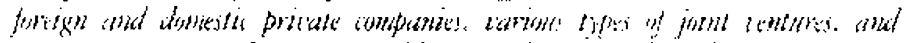

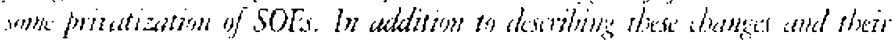

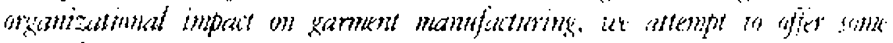

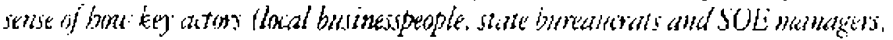

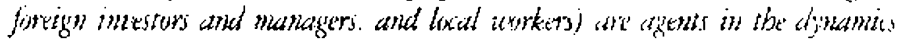

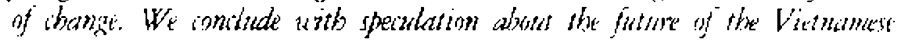

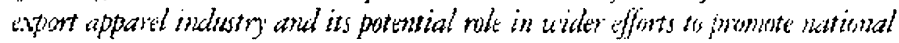
uomomic denelopment.

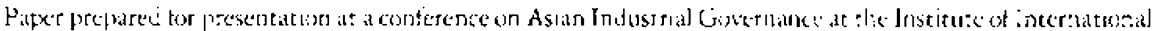

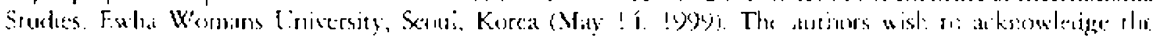
kinc assistanice of Dennis Downey for acading an earlicr dratt

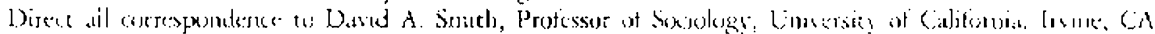

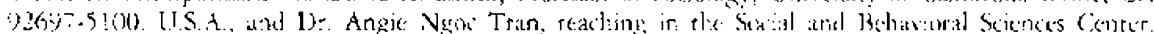

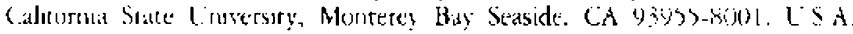




\section{INTRODUCTION}

$\mathrm{T}$ he Pacific Rim has actracted a great deal of atcention from scxial scicmists in the final decade of the wentieth entury. Early on, the region was hailed as the locus of "manufacturing miracles" (Gereffi and Wyman 1900), with some analysts confidently predicting that we were witnessing the beginning of a veritable "Pacific century" (Gribney 1993). More recently, of course, apocalyptic: accounts of "rhe Fast Asian crisis" predominate. prompting some writers to suggest that the "cconomic mirack" in the region might turn out to be an "economic mirage" (McLeod and Garnaut 1998).

There is something deeply un-nerving about the way in which many scholars and pundits suddenly reversed themselves, when thirty years of growth in the East Asian "tigurs" was followed by a few months of economic stagnation. There is good reason to be skeptical about post hoc assessments of how inherently flawed East $A$ sian economies were post-crisis, especially when a few months before, many of the same cconomic experts were trumpeting "the Asian moxdel" and searching for the keys to its success! Mainstream media depictions of deep-seated problems of crony capitalisn and "economic statism" touted the crisis as an opportunity for economic reform toward more tational Li.S.-style nero-liberalism. But a number of more critical views about the nature of the East Asian crisis and its causes and consequences cast doubt on this "conventional wisdom" (Cunnings 19)8; Yex 1998: Wade and Veneroso 1998; or Sinith 1999).

Regardless of our perspective on the recent crisis, there is very little doubt that East Asian conomic growth and development has been very dynamic in the long run. There are a number of distiner ways to explain the "motor" of the region's decades of growth. Some cling to old "culturalist" daims about Confucianism (Pye 1985; see also Singaporean Prime Minister Lee Kuan Yew cited in Kim 1998, 432-33) while a few economists argue (despite evidence to the contrary!) that the basis of the expansive growth was really "free markers" (Belassa 1987; World Bank 1993). But others focus on more sociological and polieical-conomic explanations that stress on "developmentalist states" (Cold 1986; Amsden 1989; Appelbaum and Henderson 1992; Evans 1995; World Bank 1997). or stress the ways that East Asian social networks promote business (Orru, Biggart and Hamilon 1992; Gerlach 1992; Whitely 1992).

These latter approaches, emphasizing business and political institutions and organizations and the way that they are connected and coordinated, are all efforts to understand industrial gonmunte. They focus empirical attention on the pattern of relationships between business organizations, states, and key individual and collective actors, as they grapple witl problems of economic development and inclustrial upgradity, particularly the development, production, and marketing of goods and scrvices. These organizational patrerns often emerge from socially embedded relationships inherited from the past, and they are of ten sector or industry specific. Our premise in studying these governance arrangements is that they uten hold the key to the relative success of "industrial upgrading" and, ultimately, divergent national economic performance. In the case of East Asia, establishing internationally competitive export manufacturing was an integral aspect of this (Gereffi 
1\%) 2), which meant that governatrece arrangements, out of accessity. took on at transwational diaracter.

Most of the existing rescarch on this sort of cconomic grovernance centers on distinct patrerns among the relatively industrialized "four tigers" of Sourh Korea, Tawan, Hong Kong, and Singapore, even the spectacular rise of post-war Japan. There is the difference between a highly centralized, vertically-organized, state-coordinated corporate pattern of oryantization in Japan and South Korea (Johnson 1982; Amsden 1989) versus rhe relatively loose horizontally-integrated, network-based business groups favored by the Chinese in 'Iawwan, Hong Kong, the mainland and elsewhere (Redding 19\%(); Whitely' 1992, 1996; Liu 1998\%. Debates center around the relative advantages and disaldvantages of these contrasting forms both in the early stages of development of export-oriconted industrialization, as well as their institutional appropriateness now as these economies are trying to recover from the regional crisis.

In our research on Viernam we are also interested in issues of industrial governance in East Asia, and both Pacific Rim connections and intetnational export competitiveness are crucial in this case, too. But in some signiticant ways our study of the emerging Vietnamesc apprarcl industry is distinct.

First, while Vietnam shares many characteristics with other countrics in this fast-growing region, and its political and business leaders are intrigued by the prosplece of becoming the latest "riger," this is also an "economy in transition." Fiven today Vietnam is scill ruled by the Communist Party and nominally commitced to its idonlogy, although the econony has now undergone almost two decades of reform (Tran and Smith 1999). Thus, the society is dealing with many issues intrinsic to a transition from a command towart a masket econumy.

Second. Vietnam is just at the very beginning of the patl toward industrialization and development. Its gross national product per capti for 1947 was $\$ 330$ (source

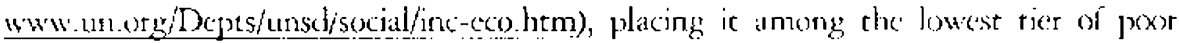
countries, far bxhind most of its East Asian neighbors. Furdhermure, Viernam's cconomic structure remains skewed toward agriculeure and exeractive activitics (i.b. raw materials, particularly oil). As of 1998 , the only manufactured goods to break into the councry's top ten export goods were "garments and textiles" (see Kim 1994 for carlier data). Despite the onset of the East Asian financial crisis in late 199?, Vietnam s textile and garment exports did not decline, but remained the same level (U.S.S1.35 billion in 19)?. LiS.\$1.351 billion the following year). In lyos they retained their rop expore sput (alacad of oil $[\$ 1.2$ billion], rice [\$1.1 billion], and shoes [ $\$$ \& 0 billiont). The leading destinations for these cextile and garment exports wete Japan (S32] mithion). Germany (\$236 million), Taiwan (\$218 million), France (\$68 million), South Korea (\$40) nillion), and Singapore (\$3.3 million). But Russia (\$5) million) and other castern

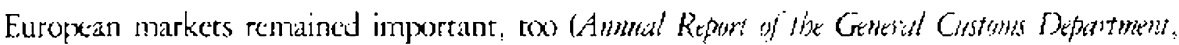
December 1998).

Finally, Vietnam is distinctive because of its peculiat getpolitical history. It survived a devastating war with a supxpower, but was subsequently labeled a parial stace by 
the United States and suffered from western-imposed international isolation. For many years its main cconomic ties were to the liast Bloc conturies, with limited trade and invesment relatious with capitalist East Asia and somc western European countries. With the collapse of eastern European communism in 1989, Vietnam looked rapicidy to renew ties with the Europxan Union, Japan, ASEA.V (Associate of Southeast Asian Nation), and the East Asian "tigers" as a source of investment capital and a market for Vietnamese goods. But as late as 1999, Vietnam still does nut have the type of "normal" trade relations with the Linited States, the world's richest source of capital and most lucrative market, that "Most lavored Narion" (MFN) status would permut (something that the Communist Party-ruled People's Republic of (hina hats enjoyed for some tinke).

This paper will foxus on the emergence of the export applarel industry in Victnam, which has grown rapidly in the pase decade as it hecame more intcgrated into global markets. After some brief comments about how global economic restructuring affects the global sourcing of garment production in the Asian Pacific Rin, we will provide a sketch of the recent history of the Viecnamese textile and gatment industrics. This analysis will foxus on the changes of the last ten years, as sectoral output and export volunes have increased dramatically, foreign investment has surged, and an industrial structure that was once the exclusive domain of state owned enterprises (SOLs) went through various types of "reform," including the emergence of foreign and domestic private companies, various types of joint ventures, and some privatization of SOFs. In this section we will attempt to provide an overview of main contours of change in industrial governance, as well as some sense of how the main actors-local businesspeople, state bureaucrats and SOE managers, foreign investors and "buyers", and local workerscontributed to this dynamic (by necessity, the treatment here will $b c$ illustrative and ancedotal- for the more complete version, see Smith and Tran, forthcoming). Finally, we conclude with some speculation about future directions for the Vietmanest export apparel industry.

\section{GLOBAL RESTRLCTURING, FLEXIBIE PRODUCTION \& EAST ASIAN EXPORTS}

To some extcnt "globalization" and "global restructuring" are tashionable catchphrases, with a pletlora of meanings (Smith and Borocz 1945; Smith, Solinger, and Topik 1999). But it is diffecult to ignore some basic changes in the world-economy in recent decades. Some claim that the main dynamic has been the rise of a "new international divisien of labor" (NII)L) (Frobel, Heinrichs, and Kreye 1981) in which a "global asscmbly line" driven by the relentless search for cheap labor emerged in the 1970 s and 1980 ( 2 (Feuntes and Ehrenreich 1984). This process leads to "deindust rialization" in the "advanced" countries, and now ever in mid-level East Asian "rigers" (Smith (\%)6), but little real development in che pror countries where the factories locite. Ohhers take a more sanguine view. Ihey see techuological and organizational imnovations pushing the world over a new 
"industrial divide" (Piore and Sabel 1984) and into growing "flexible production" (Scott 1988). In this reginx, nations nust reconfigure organizations and insticutions to maintain global competiriveness (Porter 1990). P(or countries can achicve grauine economic development by exploiting distinct "export niches" and contimuously engaging in "industrial upgrading" (Gereffi 1992). "Flexibility" in a labor-intensive sector which is extremely quality- and fashion-sensitive is particularly critical in export apparcl production where the rapid delivery of small "batch" runs at a reasonable cost is crucial (Elson 1989); Dicken 1942, (hapter 8).

In everyday parlance flexibility is usually seen as a beneficial thing, something that is unambiguously positive for business organizations and for chose within them. But conomic flexibility in an industry like garment prothetion has more complex inplications. It refers to organizations' "ability to adjust theis activities to uncertainty and to rajpidly changing conditions brought about by competition" (Malecki 1991, 202). liequently, knowledge intensive high technology sectors like semiconductors or compures software, staffed by skilled workers with access to innovative technologies, are spotlighted to cpitomize flexibility. Clearly, in these sectors both technolugical and organizational innovation aret crucial paths to enhanced competitiveness. But other industrics show ebat flexibility is multifacered and includes a darker side, which can lx inimical to both workers and genuine industrial upgrading. Flexibility frequently inwolves large anounts of sulxontracting, remporary and casual workers, and aggressive anti-union practices, ats Deyos (1995) demonstrates in his work on Thai automobile factories. Indeed, insofar as flexibiliry calls for simutaneously lowering production costs while quickly responding to frequent matket changes, it has strong appeal to all inclustries that involve tight courdination betweet design, production, and marketing. Dickens (I 9 )2. Chapter 8) points out that fashion apparel is an excellent example. To succed in a ruthessly competitive business, companics need access to information and inmovation (i.e. fashion design) and linkages to suppliers, buyers, production partners, and marketing ourlets.

Global garment preduction is dominated by what Gereffi (19) f) atls buyer-driven commoxdity chains, in which "large retailers", brand-named marketers, and trading companies play a pirotal role in setting up decentralized production networks in a wide range of exporcing countries (Appelbaum and Gereffi 1994, 44). This is a relatively new, more flexible form of industrial organization than the old corporate model of capital and technology-intensive transnational firms in sectors like automobiles or electronics, which used "producer-driven chains" in which "large industrial cnecrprises play the central role in controlling the production system" (ibid). In these buyer-driven commodity chains, profits "derive not from sale, volume, and technological advances as in producer driven chains, bue racher from unique combinations of high-value research, design, sales, after-sales services, masketing and financial services that allow buyers and branded merchandisers to act as strategic brokers in linking overseas factories and tradets with evolving product niches in the main consumer markets" (Gereffi 1994, 99). From the perspective of government officials and businesspeople in the Vietnamese extile and garment industries, the initial goal is to establesh a repuration for quality production in key "niches" so that they 
can become "linked" into these chains. Subsecjuently, the strategy shifts to kevising ways 10 position this sector so that it "moves up" from simple latwr-intensive scwing to some of the more protitable acrivities, while simultaneously limiting the power of the "brokers" mentioned above.

One premisc of our work is that states in peripheral countries like Vietnam are a potentially crucial factor in this effort to bring about economic transformation. Given the enornous global power of the transnational firms that are the buyers and control the brand mames (and their ability to play geographically dispersed factories off against onc another), governments may be the only effective counternweight in these situations. Victnam's relatively strong authoritarian state might have some advantages, if it develops the bureaucratic competency and technological sophistication to promulgate effective policies.

Of course, this takes us into ideologically-charged theoretically-disputed ground. Neoclassical economists daim that states are "rent-seeking" entities which offer a haven for unproductive activities (Krueger 1974; Buchanan, Tollison, and Tullock 1980). In the 1980 )s this image became the basis for policy-making via "ylobal neoliberalism" that called for "dismanting stares" and "freeing markets" throughout the developing world. Armed with evidence from the Last Asian "miracles," other scholars arguc that "developmental states" play pivotal roles in industrial cransformation (Anosden 1989; Wade 1900) Evans 1995): the key is to understand the details of state "intervention," and the relationship between governments and local and multinational business. While this doxs not mean that all or even most states are capable of playing this sort of constructive tole (and some states to use Evan's term are more "predatory" than "developmental"), it suggests that the historical pattern of East Asian growth has been guided by various degrees of state intervention and that this might be an important component of Vietnanis reintegration into the contemporary global country. Ilice role of the state is further complicated, in this case, first by geopelitics and C.S. tradk policy, and sccond, by the continued importance of textile and garment SOFs as key manufacturers and exporters.

\section{VIETNAM'S EVOLVING PLACE IN GLOBAL GARMENT SOURCING}

Export-oriented garment manufacturing in East Asia cook ofl in the carly 1960 ) and was a ke'y lactor at the onset of the "economic miales" that vecurred in Hong Kong, Souch Korea, and Taiwan in the 1970s (Bonacich ansl Waller 1994). By the ly80s, East Asian nations clustered among the top cen cxporters and fully one-third of world apparel exports came from this region, with much of these destined for the U.S. market (Appelbaum, Smith, and Christerson 1993, 190). But recently there has been a dramaric shift awdy from the previously industrialized ecommies within East Asia, toward China and the lower-wage countries of Southeast Asia (Smith 1996), includity Vietnan.

Vietnam has a long tradition of fine handicraft garment and texcile production. But expore oriented industrial manufacturing of apparel to non-Last 13 loc nations is new. Prior to the lare 1980 s market liberalization, the country's garmese factories were under 
the control of CONFECTIMEX, is state monopoly which mainly produced for the internal market and some East Blox allies. In 1987, Vietnam signed a series of trade agreements with the Soviet Union guaranteeing the export of over 150 million textile and garment products uver a three year period. As late as 1991 most Viernamese cextile and yarment firms uperated under government agreements to export over 90 percent of their products to the LSSR and eastern European countries in exchange for heavy machinery and to pay off national debts to these nations. While most of the exports to the Last Blox was produced in state firms, reforns in late 1988 and 1989 stimulated the rise of many new private firms in this sector. Furthermore, amendments to the forcign investment law in June 1990 opened the door for forcign dircet investment (FDI) and the emergence of joint ventures and business cooperation contracts in the textile and garment sector. Their exports were mostly working clorhes and uniforms, made with Vietnamese fabrics and accessories, but of mixtest quality and limited variety.

The last decade has been one of both impressive growth and fundamencal reorientation in the Vietnamese garment industry. Vietnam is now emerging as a production sourcing point for global apparel commodity chains oriented to the affluent markets of Japan, Western Eurupe, and North Amcrica. Exports have grow'n over ten-fold in the past decate (sce Table 1). Today the industry is large and was expanding rapidly before experiencing the effects of "the Asian crisis" in 1998. As of early 1929, it officially employed over half a million workers (see Table 2), atout one-tifth of the nation's manufacturing workforce (this number may actually be low because it misses part-time and home workers in the garment industry). The sector turned out 1.35 billion dollars of exports in 1998, which is just under 15 percent of the country's total- and exceeds the value of any other exported commodity, including Vietnan's lucrative petroleum exports. Building from the retorms of $1988-90$, the milustry now shows striking diversity in ownership stnkture and organization, ranging from giant 100 percent foreigu-t)wned textile mills, various barge-siale joint ventute arrangements with overseas investors, and hig state-run multi-factory garment and fabric firms, to very small private sewing shops that employ a handful of people and rural provincial enterprises that rely almost exclusively on the age-old "purting out" homework system.

Given the size of the industry, the array of different ownership types, the multitude of geogrtaphically. physically, and institutionally distinct production setcings, attempting to capture all the complexicies of this sector is inpossible, especially in a relatively short paper. Instead, the following section will try to oucline the main contours and changes in the industrial governance arrangements over the past decade, and sketch the impacts that some of the main actors have had in shaping them.

\section{THE 1990S: RAPID GROWIH AND ORGANIZATIONAL CHANGE}

There is litele douto that the early 199()s was a periox of rapid economic growth and a tirne when various market reforms were consolidated in Vicuam. Economic growth 
rates accelerated in the first half of the decade and the industrial output of the non-state secror, while still relatively modest, doubled. In addition, boch foreign investrnent and overscas trade burgeoned. (For an overview of this periox of reform and its economic effects and social impacts, see Tran and Smith 1999).

As a leading industrial sector, the Victnamese textile and garment industry was a focal point for these changes. Whereas in the previous decade there were a variety of "fence-breaking" activities that gradualy and unevenly moved factories and enterprises away from a rigid command economy model and began to upen the industry up to overseas investors and impores, the pace of change picked up speed in the early 192)s.

By 1991 most large Vietnamese textile and garment firms had begun to teorient their target markets away from the former Fastern Blox and towird Western markets, particularly the European Community (EC), Canada, Sandinavia, Japan, and the East Asian Newly Industrialized Economies(NICs). This dcyelopment was aided by rising wage pressures in countries like Tawan, Hong Kong, and South Korea, which were beginning to seck lower-wage production sourcing in Southeast Asia (Smith 1996). In December 19)2, Vietnam signed a major trade agrecment with the EC establishing gradually rising export guotas in 151 garment categories (Tran 1997). Obviously, access to this relarively large and lucrative market was crucial to the industry's growth, especially in light of the continued U.S. embargo, which isolated Vietnam from the biggest and richest joxol of consuners in the world. Even after the end of the cmbargo in July 1995, high tariff rates (associated with the lack of MFN status) effectively "closc" the U.S. market. But the Vietnamese state was also proactively maintaining markets in the East: in 1993 a delcgation from the Ministry of Light Industry craveled to Russia and castern Lurope to revive conmercial relationships that had atropliced in the post-1989 period.

While stace firms continued to dominare production in both the textile and garment sectors in the carly 1990 s, accounting for 60 to 70 percent of production, relatively low barriers to entry made the industry particularly atractive to newly formed private firms. Kesponding to legislation passed in the 1991 year that set guidelines for the establishment of private sector companies, by 1997 there were over 900 private (u'sth at least some foreign and domestic investment) textile and garment firms in Vietnam (lable 2).

Overscas investors were interesed, too. They have tended to prefer investment in wholly owned firms and business cooperation contracts (BCCs) racher that st and dard jointventures. While 100 percent forcign owned firms and joint-ventures create new legal entities, BCCS are contracts of joint production and distribution of specified products; all terms such as objectives, scopes, rights, obligations, and liabilities of the partics are stated in the contract. BCCs allow both sides to maintain their own accounting systems while still enjuying special tax incentives unavailable to regular business contracts (Phap Ly Publishing House 1991, 7). Whereas prior to 1991, there were only 10 encerprises with any FDl, by 1995 there were 44 domestic-forcign joint ventures, 108 wholly torcign-owned firms, and 153 BCCs between local and overseas firms.

Fven the large national state firens were affected by the reform as they gained more 
auconomy in proxluction and trade. Beginning in 1991. these SOEs could trade directly with non-Commurist markets, without going through the state corporations of CONFECITMEX (which oversaw state garment firms) or TEXTIMEX (which played a similar role for textile firms), though in the last instance they did remain under the contrul of the relevant government ministries.

\section{Cbanging Industrial Governance.}

The emergence of private and para-statist irstitutions to promoce garment exports was another significant innovation in industrial governacke during this period. The Victnamese Chamber of Commerce (VC.CI), a para-statist organization, is a promotionoriented business asscciation. It facilitates overseas investment by reassuring foreign firms that intellectual property such as patents, trademarks, and copyrights are protected. It has also worked actively to culcivate new markets for Vietnamese exports. One strategy is to organize overscas trade shows, like the 1994 VIETFXPO, the first Vietnamese trade fair in the Lnited States, where 24 of the 118 participating firms produced garments and texciles. In 1993, private firms formed the southern-based Assuciation for Wicaving, Clothing, and Knicting, which represented 200 member companies. This group's goals were to improve the position of private firms vis-a-vis state policics on matters such as loan regulations, taxes, land leasing, and EC cquota alloxation (though it is not clear that this organization's efforts have made much headway). In 1995 the Vietnamese government leaders made some significant policy changes designed to streamline and consolidate economic planning and export promoxion in the apparel secror. A decision was made to create a new unified state corporation called VINA'IEX intended to oversee all central state- owned textile and garment firms (local state firms remained under jurisdiction of provincial people's committces). This larger "umbrella" corporation merged CONFICTIMEX and TEXTIMEX with the goal of fostering greater istegration between state firms. One of this new corporation's major goals has been to improse the quality of Vietnamese produced rextiles so that local garment factoriex can use indigenous fabric (although even in the late: 1990 most domestically prochuced rextiles are for domestic use or export to eastern Europe) (Tran 1997, 94). In its headquarters in Hanoi and Ho Chi Minh Cicy, VINATEX staff members are now linked to the Internct to closely monitor worldwide market conditions and global prices of cotton and other textile and garment inputs. It also established a fashion design center and a vocationial school, aiming 6) ipgrade garment quality co better meet increasingly sophisticated consumer demands. However, as of now, this effore has juse begun to serve the domestic market. VINATEX remains under sare bureaucratic control. The newly formed Ministry of Industry (combining the former Ministries of Light Industry, Heavy Industry, and Energy Industry) designs the general development strategy for the textile and garment industries, proposscs changes to its organizational structure, and nominates candidates for key managenent posts within VINATEX. 'The Ministry of Finance now exerts strict financial controls, providing accounting and audiong to VINATEX and all member firms. Mhe Ministry of Itade is charged 
with allocating specific garment quotas, though plans call for VINATEX to gradually make more of these decisions itself.

By the mid- to late-1990s it is fairly clear that three distinct types of firm ownetship in the Vietmamese apparel industry have emerged: long-established SOEs, small but rapidly proliferating locally owned private firms, and companies with some degree of foreign direct investment. Profiling each of these types provides an overicw of the basic character of che Vietnamese textile and garment industries today.

\section{State Firms.}

Most central state firms were established in the: $1950 \mathrm{~s}$ or $1960 \mathrm{~s}$. They are large and found in both the northern and southern parts of the country, and in both textile and garment production. Textile SOEs are more capiral-intensive, but they often use old and ohsolete equipment. According to a Ministry of Light Industry (MOLI) report in the early 1990s, 70 percent of the machinery used for textile manufacturing (spinning, weaving, dyeing? needed to be modernized (MOL/ Joumal, April 1993: 24-25). Most central textilers have been attempting to upgrade their machinery via linkages with foreign firms. Even though some foreign firms arc establishing high-technology, "state of the art" factorics in Victnarn now, textile employment may be declining or at least is failing to keep pace with work in the garment scwing sector (sec: Table 2). The Nam Dinh Textile Company, the biggest and oldest SOF in this sector, laid off thousands of workers in the face of huge debts and an inability to produce competitive rabrics, epitomizing serious problems (Tran 1997, 111-12). The garment SOEs are more labor-intensive but also have been able to obtain some new machinery, since equipment is much cheaper in the scwing end of production. A complete garment assembly line costs alxout U.\$.\$100,000 whereas fabric making machincry can cost many times as much. State garment firms have successfully met the challenges of upgrading proxtuction for expore while texcile firms have not. Garment SOFs take advantage of their state connection to procure financing and overseas apparel guotas. While they run relatively large factories ranging from a few hundred to two or three thousand cmployees, they are able to utilize flexible work strategies: lines can quickly change to new products and factory labor can easily be increased to meet peak demands and reduced during slatk times. While it is not as prevalent as in the private sector, some state garment firms utilize "putting out systems" where simpler components of garments are sewn by home-workers. The garment labor force in Vietnam is growing, though it still lags behind the textile workforce.

\section{Lxal Private Firms.}

As already doxumented (Table 2), this type has proliferated since it became a legal option in the early 1990s. These types of businesses tend to be concentrated in the south. in and around Ho (hi Minh City. Private textile firms are wsually small housthold 
production units, producing for direct sale at indigenous markets or serving garment tactorics prokducing apparel for eastern Europxan markcts. The few garment firms that try to link up to the Western export trade are usually subcontractors for conpanies from Japan or the Fast Asian NICS. In interview's with the authors, the Victnancsc garment entrejereneurs express frustration with state export promotion policics such as quota allocation and fiscal policies (for instance, interest races for lending and credit) that tend to privilege state firms. However, since the boundaries between statc and non-state firms are becoming increasingly blurry over time (given the multi-level subcontracting between domestic firms), we need to examinc this issue more fully (for a more in-depth analysis on the increasingly symbiotic relationships between state and private capital, sec Tran 2001).

\section{Foreign Investruent.}

This category is a hit heterogeneous. It includes joint ventures, 100) percent foreign owned firms, and BCCs. The motivation behind this inflow of foreign capital is pretry clear: Vietnam as a location for manufacturing provides relatively cheap labor costs. With changes in investment and trade laws, FDI climbed steadily. By 19y7 FDI accounted for 17 percent of Vicenam's total trade value (Tran and Smith 1999, 81). Tables 3-8 give extensive data on foreign investment in both the textile and garment industry by source country, receiving provines and type of firm. In Talsles 3 and 4 , it is otovious that the rotal value of capital is much higher in textiles than apprasel, reflecting this sector's higher capital incensity. There is also a clear East Asian regrional pattern: Japan, South Korea, Taiwan, and Hong Kong are among the top six investors in borh areas, with the Koreans leading the way in textiles and the Taiwanese in garments. The next two tables (5 and 6 ) show a strong investor preference for the Sourh, which overwhelmingly favors textile production over garment making. Finally, tables 7 and 8 show the distribution of investment irito joint ventures, wholly-owned subsidiaries, and BCCs (the latter secms to be the preferred investor strategy), though 100 percent foreign ownership, especially in the textile industry, may be gaining popularity in the last fiw yours.

The Fast Asian NIC connection merits a brief commont. Vietnam lowks attracrive to these firms because of cheap labor and unfilled garment quotas fior export to the Europear Union. Many Tawancse, Koreans, and overscas Chinese from Singaryore or Tawan have come to Vietnam as factory managers oversecing production on lxehalf of Easc Asian and Western buyers, of en equipping factories with used machiocry transferred from their homelands. In the textile sector there's cvidence that entuch of the recent investment is to esrablish wholly-owned foreign companies. On the ocher hand, BCCS and joint ventures remain popular in garment and accessory preduction. Most of these collaburative business deals are with SOEs.

There is little doubt that the surge of forejgr capital has been a dynanje force in thexe industries. There has clearly been some technology transter, for example, especially in the textile sector where Vietnanese froms gain access to new and expensive equipment 
that would be otherwise unavailable. East Asian company links to factories producing finished garnents provide casicr access to western export markets. But some linitations exist (the following discussion is paraphrased from Tran and Smith 1999, 81-82). First, there is a gap between the registered capital investment planned and permitted and the actual amount invested as of June 1998, for instance, only about 10 percent of the investments had materialized. This suggests there may be some issues (bureaucratic rules, lack of investor confidence) that have slowed investmenc in Victnam. Second, FDI in textile and garment factories accumulates relatively low value-added as discussed above, much of the profits in the global apparel commodity chain are realized at "higher levels" via design, advertising, and marketing. Thus, both the workers' wages and businesses' profits that stay in Vietnam are fairly low.

\section{COMPE'IING INTERESTS \& ORGANIZATIONAL CHANGE}

'The previous section outlines the basic structure and recent charlges in the Viernamese apparel industry. It oudlines the generic characteristics of the sector's still emerging pateern. of industrial governance. Scattered through this discussion are references to the actions of pople and groups; thus economic governance siructures do not just "volve," they are made via the collective action of a variety of key acturs. Sometimes this is a planned, purposive process, at other times it is the result of unintended consequences; sometimes changes occur because of conflicts with other social, economic, and political interests and groups, other times they are the result of broad cooperation.

In this brief paper we can do little more than highlight some key groups (both within and beyond Victnam) who appear to play crucial roles as acturs shaping the urganizatoon and governance of the textile and apparel sector, and suggest how these groups have atcompted to further their own interests via "cconomic reform" and global reintegration. The following observations are based on our own rescarch (including extensive fieldwork in Vietnam). Herc we simply summarize: the details will apptar later (Smith and Tran, forchcoming).

Within Vietnam the two most obvious groups intluencing changes within the industry are I) the managers and owners of tactories, and 2) the state bureaucrats boch in VINAIEX as well as in the state's coconornic ministries. We'll discuss cach of these constituencies, and some significan differences within them. But we wart to remind readers that workersthe people whose combination of cuality work and low compenation has been critical thus far-could be crucial, too. International players are also important, especially foreign investors and various apparel "buyers" and "middlemen" who mediate berween overseas firmis and local facturies.

During our fieldwork we interviewed a number of Vietnancse garment factory managers and owners. Currently, most of the largest, most dynamic export garment fitms are SOEs. While generalization is perilous, our factory visits suggest that at least some of these state managers are proud of their firms' accomplishments, dedicated to imptoving 
their ow r business skills, and eager to incorporate eechnofogical upgrading and organizational innovation. Managers seem eager to boost che competitiveness of their own firms by enhaning guality and efficiency. For instance, the woman manager of a latge garment factory outside of Hanos that we visited in July 1998 had recently heen at a seminat on international business at Dartmouth Unversity. It is in state-firm managers' sclf interest for the encire Vietnamese garment industry 10 move toward various types of industrial upgrading and beter improve connections to the western marker. But this group also bxetits to some degree from statc firms current privileged access to credit. cxport quota, and state officials. Private factory uwners do not have thuse advantages, as they are quick to point out. These entrepreneurs entered the business just a tew years ago, after reforms made privare companies possible (though some have tamily histories of involvement in garment-making). But while they rur smaller-scale operations, sonxof these owners are moving into expore production and aspire to the sarne managrerial and technical skills and voice many of the same concerns alout mancuvering into partncrship relations with overseas firms that we heard from state firm managers. For instance, the daughter-in-law of the woman who owned a medium-sized fanily garment firm in Hanoi had just returned from a global business seminar at the University of Delaware. While complaining about the way state policy disadvantages private firms, she also described how the fim managed to secure quota allocations and bargained with a series of East Astan partner firms.

State bureaucrats may ulimately hold the key to the degree of success that the Vicuamese textile and garment industries achieve. Despite efforts to consolidate (via VINATEX and the Ministry of Induscry), some coordination problems may remain (especially with different government ministries overseeing trade, finance and industrial planning). VINATEX appears to to trying to make itself a center tor technical competency and organizational expercisc though there seem to be some "mixed nessages" about how far indigenous technology and design capacity can go. Ministry officials who we interviewed scemed to be knowledgeable about the constraints of the international econony and the linsted economic growth potential for low-wage garment sourcing. The 2010 Plan demonstrates an eagerness to outline long-range plans and goals. One clear priority is co encourage cocton cultivation and upgrade rextile protucrion so that Viernamesc export garments can contain more locally produced tabrics. According to the central state plan, VINATEX is charged with implementing it, making sure that statc capital is dise ributed to all provinces, and trying to attract foreign and domestic capital. especially: for coten growing and weaving, and dyeing shuttle plants (The Genthat Plan of VTG Deteloputen "Yed 2010, VINATEX, April 1997). There scems to lx a druving nationalist comminmerst anong burcaucratic cadre to promotc industrial upgrading and enlance international comperitiveness consistent with the image of a "developmentalist" statc. Wherher the Victnamess stare and its various ministries can develop the technical and organizarional competence while remaining "autonomous" enough to avoid corruprion is yet to be seen. Further, the recent East Asian crisis underscorss the degrec to which the fate of the national industry is vulnerable to the vicissitudes of the global market. 
The rapid currency depreciation in other Southeast Asian countrics (Thatland, Malaysia, and Indonesia) suddenly undercut the wage competitiveness of Vietnamese-produced garments, even though wages in Vietnam remaned very low.

These rather poorly paid workers (average wayes alouut i0 50 C.S. dollars per month) are a final significant domestic constituency to consider. There have been some nutable examples of labor unress and strikes, parcicularly at foreign-non factories. Furthermore, there are many instances of worker protests and resistance to control and discipline on the shop-floor, particularly among women workers, who comprise over 80 percent of the textile and garment workforce (for a detailed analysis see Tran 1999). But as yet it is hard to sce a coherent national labor movement emerging (and labor organizing arnong textile and garment workers is notoriously difficult). But currently there are well uver half a million Vietnamese working in this industry. If nothing cise, is is obvious that state officials are mindful of the "labor absorbing" nature of these factories and view the preservacion of jobs as an important goal. But this highlights the need to examine the possible contradictions between policies promoting cheap and complant labor in order to attract foreign investment, and the real protection of workers rights. In the history of industrialization in rich "core" countries worker organization and demands for higher wages actually promoted various kinds of "industrial upgrading," as business interests were forced to improve quality and efficiency in the tace of rising costs (B)ock I977). (jiven the current global situation of "footloose capital" especially in the garment huyer-driven commodity chain where wate costs often lead to indostrial rekxation this dynamic is difficult to predicr.

While there are clearly indications that a constellation of domestic intercsts can $x_{x}$ counted on to promote "industrial upgrading", the intcrnational actors are certainly more disinterested. Foreign investors want to make a profit, but many view Vietnam as a place where that depends on cheap labor costs, not on improved manufacturing or better quality goods. The East $A$ sian middlemen, who manage lactories or serve as "quality control" inspectors do care about time delivery and crror-free sewing, lut they are not concersed with kow dothing is produced (high-grade "putting out work is finc), and it is clearly against their own interests for Victnamese firms to atcmpt to establish direct links to end markets or move into design. From the Virtnamese perspective, an obvious stratcgy to create more local profit is to "eliminate middlemen" from the commodity chain and deal directly with the buyers. This creates a structural tension between Vietnamese producers and workers and Korean and Taiwanese factorymen and investors.

At a macro level, global pressure comes from international agencies like the United Nations Development Program (UNDP), International Monetary Fund (IMF), and the World Bank. Space precludes much discussion of this, but acceding to these agencies' advice can have mixed developmental effects. On the one hand, evidence suggests that ayencies like the IMF or World Bank often promote ideological agendas like global neo-liberalism rather than tailoring programs to fit the particular economic needs of specitic countries (Bello and Rosenfeld 1990; Smith 1999). On the other hand, the history 
of Vietnam's reforms suggests that "praymatically yielding to IMF" and LNDP recommendations help lay the foundations for the robust economic erowth of the 1980)" (Iran and Smith 194\%), 75). But for this policy to succeed, state burcaucracy should be compecent and insulated enough to be pragmatio and negotiate deals that do meet natumal developmetital priorities.

\section{LOOKING TO THE FL'TURE}

This paper provides a brief history, an overiew of the organizational struture, and a quick inventory of the key actors in the Vietnamese apparel industry as it re-linked into global sourcing networks in the 1990s. In ternis of gencral issues of "industrial governance," we tried to convey both the move toward a more market-oricnted cconomy, as well as the continuing key role of the state. The relevarte state miniseries, VINATEX (and its forerunners), and garment and textile SOEs have tricel to coordinate the growth of this manufacturing sector with the relarively recent arrival of both forcign and domescic capical. 12efying stereotypes, SOEs remain the main partners of foreign buyers and manufacturers, and SOEs frequently subcontract their work out to domestic private firms. The old "scates versus markets" debate becomes almost completely meaningless under thesc conditions. Indeed, the "soxiadist" state, offen in response to pressures and demands from non-state accors, plays a role in helping to shate the cmergence of a market-eriented industrial governanke regime.

White the Vicenamese state has been critically impurtant in the overall trajectory of econumic reform, as well as the more specific cmergence of the export garment sector, the patcern is very differenc from the sort of "developmentalist states" Evans and others identified in Japan, Sourh Korea or Taiwan. On the negative side. it is not entirty clear that the Vietnamese state and its various economic ministries have risen to a sufficiently hight level of "embedded autonomy"(Evans 1995). But, on the orher hand, it is unclear whether the type of lumbering giant state needed to control the giant "Fordist" corporations of the older Japancse and Kurtan model is relevante to the Vietnamese case. Referring to China and Vietnim, McCormick (1998, 127) says, "Eintry into the world comomy has shifted pxower away from central authorities... forcign investors require a Rexibility found only at lower levels and in smaller organizations." This suggests that the statte must make even more room for coexistence with a growing private sector. 'I'he type of developmental state best suited for twenty-first century realities will have to adapt to a new set of economic realitics. Certainly, a measure of flexibility will bx recuured to iompete in the frlobal garment business.

Despice all the initiatives to change industral governance already reviewed, the biggest obstack to true "industrial upgrading" in this industry will invelwe the relatively disadvancaged strucrural position in which Vietnam finds irselt as a low-wage manufacturing site. Global sourcing decision are likely to be made far away from Hanoi and Ho Chi Minh City; with considerations like wage costs entering into she global calculus of the 
major marketing and brand-name companies. On the ground in Vietnam, concerns about "cheap labor" may reinforce the foreign investors' pressure to maintain the status quo in which garment production is mainly subcontracting of the low value-added asscmblage stage, while higher value-added inputs like patcerns, and distribution and markecing services stay overseas. This reality nakes entry into garment manufacturing at the lowest levels a dubious strategy for most poor countries today if they intend to "climb up the industrial ladder." But the nationalism of the Vicrnamese people (including both businesspeople and bureaucsats) and the presence of a potential "developmentalist state" offer some hope. There seems to be a real commitment to develop upstrean and downstream industrial linkages and learn skills that could make production more efficient, leading to more exports to western markets. The prior existence of alternative markets in eastern Europe and renewed cfforts to teactivate them since the early 1990 s atter a "down" periox might provide a way of partially circumventing the western-controlled buyer commotity chains and allow more of the value-added probit to accue to Victman and its peerple. 
TABLE 1. THXTILE AND GARMENT EXPORT (YEARS BETWFEN 1981-1998)

(1:) millows of L'S. Aluiniss)

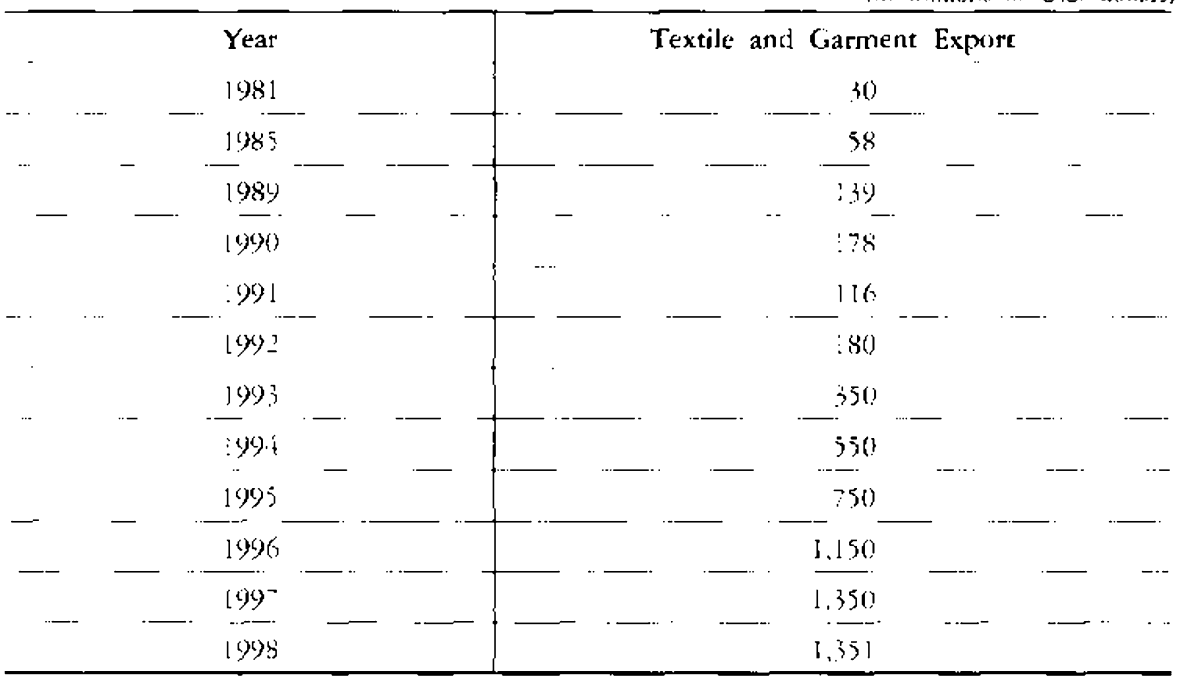

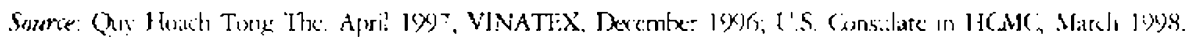

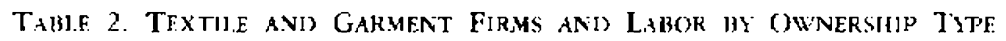
(1993, 1996, 1997)

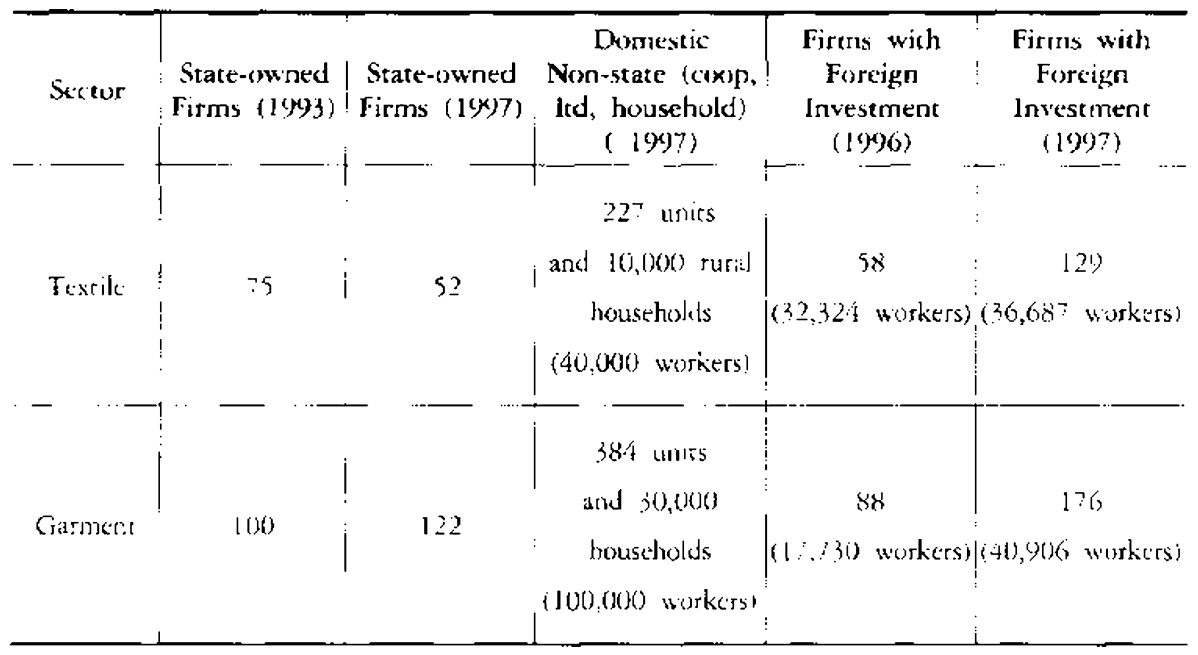

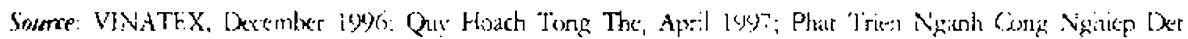

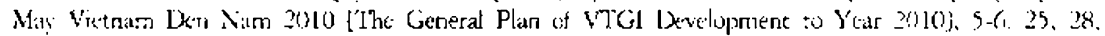

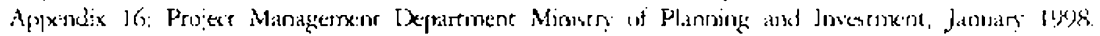


'IABI.F 3. 'TEXTII. INULSTRY FOREIGN INUTSTMENT BY ECUNOMY' (1988-1997)

(iin throusands of LiS. dollars\}

\begin{tabular}{|c|c|c|c|c|c|c|}
\hline Councry & $\begin{array}{c}\text { No. } \\
\text { Projects }\end{array}$ & $\begin{array}{l}\text { lotal } \\
\text { Capital }\end{array}$ & $\begin{array}{c}\text { I'otal } \\
\text { Disbursement: }\end{array}$ & $\begin{array}{c}\text { Iotal } \\
\text { Reverue }\end{array}$ & $\begin{array}{l}\text { lotal } \\
\text { Export }\end{array}$ & $\begin{array}{c}\text { Labor } \\
\text { (persons) }\end{array}$ \\
\hline South Korea & 28 & 675,000 & 155,500 & 183,000 & $: 24,000$ & 8801 \\
\hline Malaysia & 1 & 477000 & 184,000 & 32,000 & 19,000 & (1) \\
\hline Taman & 21 & 205,000 & 134,000 & 107,000 & 71,000 & 4940 \\
\hline Libxria & 1 & $4 ? .000$ & 196 & 141 & 1.41 & $1 ? 1$ \\
\hline Hong: Kung & 6 & $\$ 1,000$ & 3.700 & 6,200 & 5.200 & $? ? 280$ \\
\hline Luxembourg & 1 & 7,600 & 6,000 & 20,800 & 12.100 & 245 \\
\hline Japan & 1 & 6,750 & 4,500 & 96.3 & 282 & 91 \\
\hline Vorth Kures & 1 & 5,300 & 3,600 & 210 & 110 & 156 \\
\hline Prance & 1 & 5,000 & 4900 & $2 \vdots 1$ & 0 & 60 \\
\hline China & 1 & 5,000 & 0 & 0 & 0 & 8 \\
\hline Australia & 1 & 3,100 & 947 & $: 43$ & 130 & 154 \\
\hline Singapore & 1 & 3,055 & 4,000 & 10,200 & 10.200 & 300 \\
\hline Channel Islands & 1 & 1,400 & $1,40()$ & 2,600 & 2.500 & 637 \\
\hline Iotal & 65 & $1,182,205$ & $502,74.3$ & 363,408 & $24,1,663$ & 18,368 \\
\hline
\end{tabular}

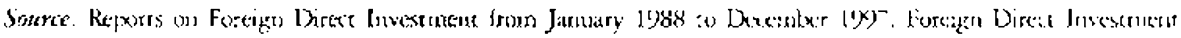
Marragencut Department of the Ministry of Plansing and lavestment.

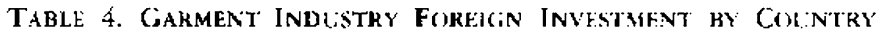
(1988-1947)

in (he)tisincis of [;.S. dollears)

\begin{tabular}{|c|c|c|c|c|c|c|}
\hline Country & $\begin{array}{c}\text { No. } \\
\text { Projects } \\
\end{array}$ & $\begin{array}{l}\text { Total } \\
\text { Capital }\end{array}$ & $\begin{array}{c}\text { Total } \\
\text { Disbursement }\end{array}$ & $\begin{array}{c}\text { Total } \\
\text { Revenue }\end{array}$ & $\begin{array}{c}\text { Total } \\
\text { Export }\end{array}$ & $\begin{array}{c}\text { Labor } \\
\text { (persons) }\end{array}$ \\
\hline Tajwan & 26 & $71,000)$ & 41.000 & 31,000 & $30,0(x)$ & 6,983 \\
\hline Japan & 15 & $.39,0000$ & 15,000 & 17,0000 & 17.000 & 1891 \\
\hline Souch Kores & 16 & 26,000 & 14,000 & 26,0000 & 25.0001 & 4.132 \\
\hline 1 Hong Kong & 13 & 22.000 & 15.000 & 36,0000 & 32.000 & 3095 \\
\hline l.jechtenstern & 1 & 18.000 & 7,200 & 38,600 & 35.060 & 1.130 \\
\hline Singug*re & 1 & 7,000 & 3,300 & 3,200 & $2.0(n)$ & 150 \\
\hline Germany & 3 & $7,0(X)$ & 6,800 & 24.1000 & $\because 4,01003$ & 77.4 \\
\hline France & 3 & 6,300 & 5,800 & 39,000 & 19.000 & 1.370 \\
\hline Thailand & 1 & 4,200 & 0 & 0 & 0 & 0 \\
\hline Camboctia & 1 & 3,100 & 2,500 & 2,300 & 2.700 & 255 \\
\hline Milaysia & 1 & 1,700 & 1,6000 & 55 & 55 & 2015 \\
\hline Russia & 1 & 1,500 & 0 & 0 & 0 & 5 \\
\hline ltaly & 1 & 1.500 & 0 & 0 & (1 & 2 \\
\hline Srı lankii & 1 & 1.500 & () & 0 & (]) & $\therefore$ \\
\hline Indenesid & 1 & 1.300 & 0 & 0 & 0 & (i \\
\hline Clinis & $?$ & 738 & 214 & 1,150 & 1,140 & 155 \\
\hline Australia & 1 & 300 & 0 & 0 & 0 & 3 \\
\hline Totil & 88 & $312, ! 38$ & $112,44 ?$ & 198,105 & 187.895 & $2(0,453$ \\
\hline
\end{tabular}

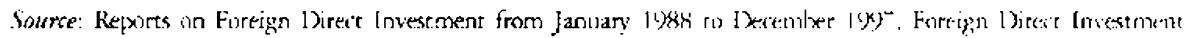
Maraugement Dxpitrtment of the Ministry of Planning and Jnvestrment. 


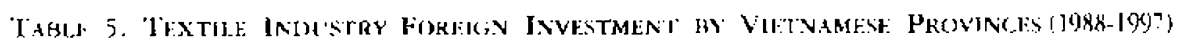

\begin{tabular}{|c|c|c|c|c|c|c|}
\hline $\begin{array}{l}\text { Regiund } \\
\text { Provincts }\end{array}$ & $\begin{array}{c}\text { No. } \\
\text { Projects }\end{array}$ & $\begin{array}{l}\text { Iotal } \\
\text { Capital }\end{array}$ & $\begin{array}{c}\text { Total } \\
\text { Tishursement }\end{array}$ & $\begin{array}{c}\text { 'lotal } \\
\text { Revenue }\end{array}$ & $\begin{array}{c}\text { Total } \\
\text { Export }\end{array}$ & $\begin{array}{c}\text { Labor } \\
\text { (persorns) }\end{array}$ \\
\hline Done Vai & $1^{7}$ & $1,05 \times, 000)$ & $294,0(10)$ & $50,000)$ & 38.100 & 1558 \\
\hline Lone fol & $i$ & 87,000 & $54,(60)$ & $21,000 !$ & 10.5011 & $J(1.30$ \\
\hline P::u It:o & 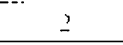 & $\because,(x) 0$ & $52,0(x)$ & 85000 & $\therefore+.0(1)$ & 3068 \\
\hline Hinlt D)แแ⿰纟一 & !) & $\because 1000$ & I 3,000 & 19000 & $1 ;, 000)$ & $1.56 i$ \\
\hline Hosl City & $? \mathrm{ij}$ & $6,(X) 10$ & 60,000 & $15 \div .000$ & siock) & 627.1 \\
\hline Tay Ninh & $\div$ & $51,0(1)$ & 1.7100 & 765 & .6 .4 & 467 \\
\hline Vung Tis & 1 & $35,0(14)$ & 0 & $\cdots$ & 0 & 3 \\
\hline Cin T:an & 1 & $6(5)$ & (1) & 0 & 0 & $\therefore$ \\
\hline Trit al Sustuts & 57 & $! .145,200$ & $\{7, ?(K)$ & 328,765 & $? 14,36 \%$ & $16-66$ \\
\hline Hili Duung & 1 & $5.3(x)$ & 3,600 & 210 & 110 & 156 \\
\hline Ha sisi & 1 & $5.00(1)$ & $(1,5)$ & 151 & () & 66 \\
\hline 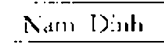 & 1 & 5,0003 & (1) & 0 & (1) & or \\
\hline Trust Nistl! & $\vdots$ & 15,300 & 8.5100 & 361 & $11 i 1$ & 330 \\
\hline l.im $I)$ ?: & $\vdots$ & $1 !, 0(k)$ & 12,900 & -1.5 .6001 & $13,20 \mathrm{ij}$ & די \\
\hline D: $\mathrm{Xing}$ & $\mathrm{i}$ & -6000 & $6,600)$ & 20.800 & 12.100 & 2015 \\
\hline Forail centria & 5 & $18(x)(0)$ & $18,2)(x 0$ & $\therefore \quad \therefore(k)$ & 25.304 & $1 \div 2$ \\
\hline
\end{tabular}

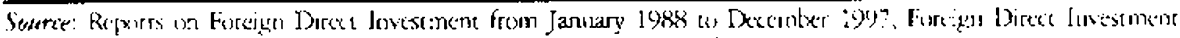

Mtan.tgement Department of the Ministry of Planning asd livest:nent.

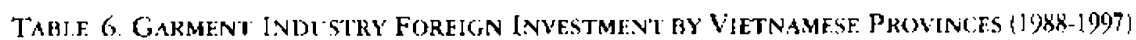

\begin{tabular}{|c|c|c|c|c|c|c|}
\hline $\begin{array}{l}\text { Region' } \\
\text { Province }\end{array}$ & $\begin{array}{c}\text { No. } \\
\text { Prujecrs }\end{array}$ & $\begin{array}{c}\text { Toral } \\
\text { Capital }\end{array}$ & $\begin{array}{c}\text { Total } \\
\text { Dishursement }\end{array}$ & $\begin{array}{l}\text { Toral } \\
\text { Revenus }\end{array}$ & $\begin{array}{l}\text { I'otal } \\
\text { Expirt }\end{array}$ & $\begin{array}{c}\text { Labur } \\
\text { (persons) }\end{array}$ \\
\hline HICN City & +2 & 83.000 & $50 .(x) 0$ & 75,0001 & $71,600 !$ & 9.552 \\
\hline D)onge Xi1 & 12 & 50.100 & $21,(N(N)$ & $550(1)(x)$ & $\therefore .500$ & $2,(1,59$ \\
\hline Birislomg & $! 1$ & (1) $(0)(x)$ & 1.1,0k1 & $\{(1,(1):)$ & $3 \because, 0) 0$ & $1, ?(1)$ \\
\hline loing in & 1 & 3.550 & $\therefore 3(6)$ & 234 & 234 & 352 \\
\hline Cisl Ther & 1 & $1,2(k)$ & 1,300 & $6,300)$ & $\because 5(11)$ & 667 \\
\hline V'uxg Tau & 1 & y55 & $891)$ & $! 2,000$ & 12.000 & 684 \\
\hline Tay Ninl & 1 & $y(x)$ & 600 & 952 & 952 & $S(x)$ \\
\hline Totall Souch & 69) & 17.7905 & 90,090 & 169.191 & $160,19]$ & 16.175 \\
\hline 1 1:L $X: i$ & 5 & $1<3.500$ & 5,100 & $1 \div 000$ & l 2000 & -452 \\
\hline ll.1i Pliung & $i$ & $-.100)$ & 4.700 & $16,0(0) !$ & 16,000 & $5 \times 4$. \\
\hline$\{1,1 \Gamma)$ & 1 & $\therefore .700$ & $1.3(1)$ & 1.9000 & $\vdots . \varphi(k)$ & $+2 ?$ \\
\hline 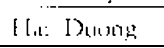 & 1 & 1.6000 & 780 & $f .50)$ & $i .5(x)$ & 350 \\
\hline 1. Bny & $?$ & 734 & 247 & $1.15,0$ & .1 .40 & 155 \\
\hline It.6 Tinh & i & $5 ? !$ & $8: 0$ & i & $i 1$ & 138 \\
\hline Qunge:inth & 1 & $3(x)$ & (]) & 0 & !! & $j$ \\
\hline Tot:il Xorch & 1.1 & $\therefore 9,46 ?$ & $12,89 \%$ & 36,750 & 35.810 & ?(x) \\
\hline Khanh Hol & I & $5.100)$ & 5,110 & 4,120 & 4.120. & 318 \\
\hline$D_{i}: \therefore a$ & 2 & $2,0(0) 0)$ & 3.300 & $3.50 i n$ & 3,5011 & $1.1 \%$ \\
\hline Lam bing & 1 & $1: \div(0)$ & $1,(50)$ & 5 & is & 305 \\
\hline (Quang & 1 & 1,500 & 1 & (: & (i) & $i$ \\
\hline$T_{1, n, l}$ rentral & 5 & $! 0 ; 3(y)$ & 9,810 & -695 & $-6 \div 5$ & $1.6(6)$ \\
\hline
\end{tabular}

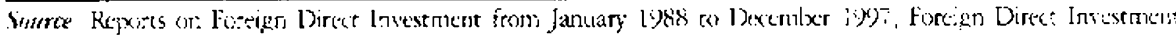

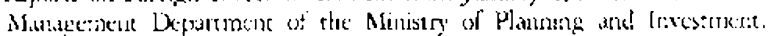




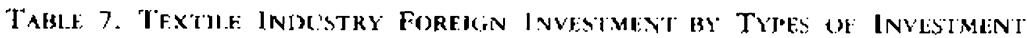
$(1988-1907)$

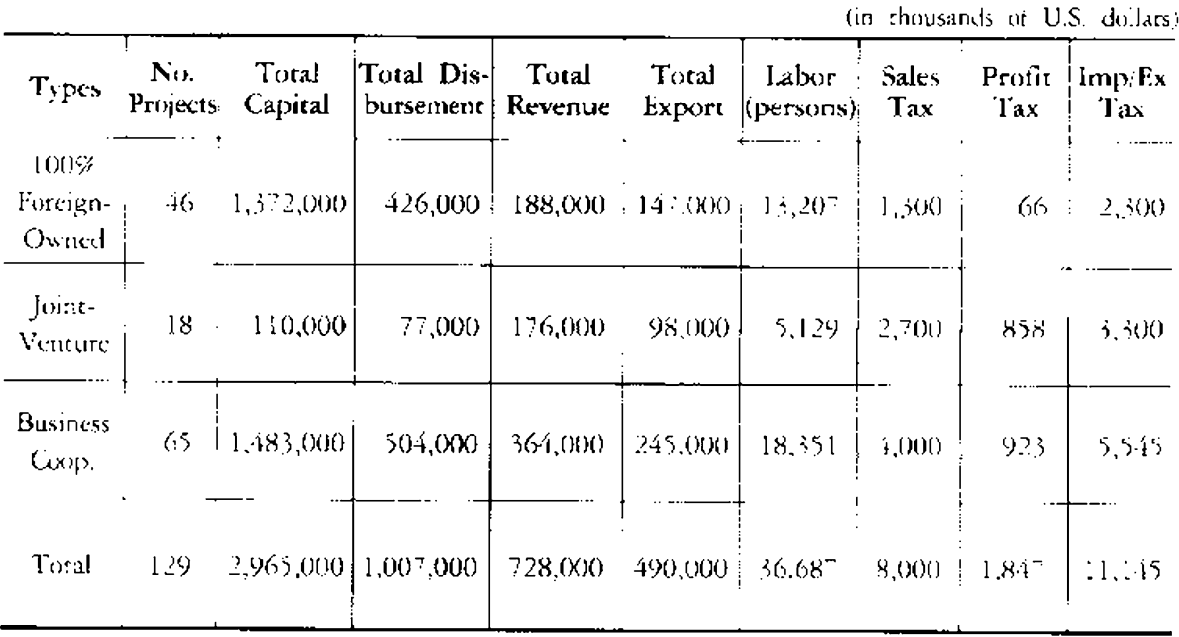

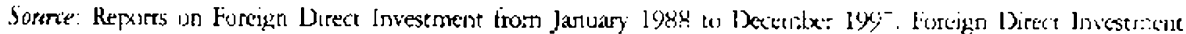

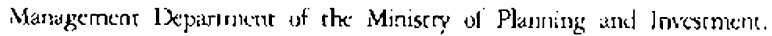

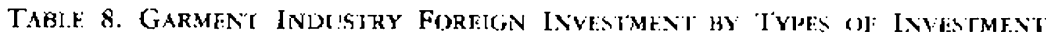
(1988-1997)

\begin{tabular}{|c|c|c|c|c|c|c|c|c|c|}
\hline Types & $\begin{array}{c}\text { Nos. } \\
\text { Projects }\end{array}$ & $\begin{array}{l}\text { Total } \\
\text { Capical }\end{array}$ & $\begin{array}{l}\text { Total Eis- } \\
\text { bursement }\end{array}$ & $\begin{array}{c}\text { Total } \\
\text { Revenus }\end{array}$ & $\begin{array}{l}\text { Tucal } \\
\text { Expurt }\end{array}$ & $\begin{array}{c}\text { Labur } \\
(p \times c x+m s)\end{array}$ & $\begin{array}{l}\text { Salcs } \\
\text { Tax }\end{array}$ & $\begin{array}{l}\text { Profit } \\
\text { Tax }\end{array}$ & $\operatorname{Impix}_{\mathrm{Tax}}$ \\
\hline $\begin{array}{l}100 \% \\
\text { Fureign- } \\
\text { Owned }\end{array}$ & 62 & 154,100 & 72,000 & 140,000 & 135.0000 & $12.88:$ & $36:$ & 1,136 & 46 \\
\hline $\begin{array}{l}\text { Joint- } \\
\text { bentise }\end{array}$ & $\vdots \ldots$ & $5.3,400(3$ & 10,000 & 58,200 & 55000 & $+.5 \div 2$ & $2 y+4$ & $2 i 0$ & i2 \\
\hline $\begin{array}{l}\text { Business } \\
\text { Coxpp. }\end{array}$ & 88 & 212,000 & 112,0000 & 198,000 & 188,0001 & 30,453 & 675 & 1.366 & $7 ;$ \\
\hline Total & $1: 6$ & 42.4 .500 & 224,000 & 396,200 & $376,0(1)$ & 40,906 & 1,310 & $2, ? ; 2$ & 156 \\
\hline
\end{tabular}

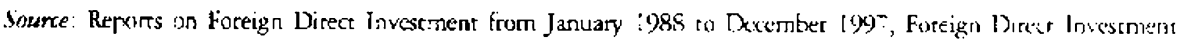

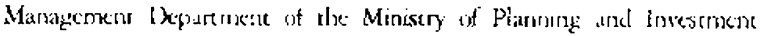




\section{REFERENCES}

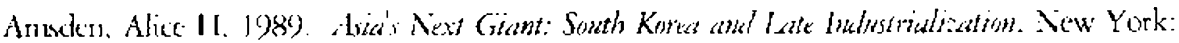
Oxford Liniversiry Press.

Appelbaum. Richard P. and Gary Gereffi. 1994. "Power and Protits in the Apparel Commodity Chain." In Globul Pnduction: Ibe Apparel Indissing in the Pasific Rim, eds. Edna Boriacich, Lucje Cheng, Norma Chunchilla, Norma Hamilton, and Paul Ong. Philark!phia, Pa.: Temple Inniversity

Appelbaum, Richard P. and Jeffrey Henderson. 19)2. Shates and Detelopment in the Asium Paific Rim. Newbury Park, Calif.: Sage.

Appelfaum, Richard, David A. Smith and Bradley Christerson. 1993. "Commodity (hains in the: Pacific Rim: Carment Trade and Manufacturing." In Commolit, Chami sme Glubst Catitalijm, eds. Gany Gereffi and Miguel Koneniewicz. Westport, Conn.: Crreenwood.

Belassa, Bela. 1981. The Newly todwitrialized Cownries in the World Eomsmm. New York: Pergamon Press.

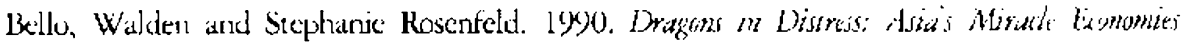
in Crivis. San Francisco, Calif.: Institute for Food and Ixvelopment Policy.

Blork, Fred. 197\%" "The Ruling Class Does Not Rule: Nores on the Marxist Theory of the State." Soxichlist Rezietc 33: 6-28.

Bunacich, Edra and David Waller. 1494. Mapping a Global lndustry: Appared Production

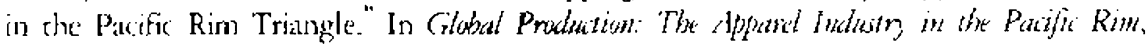
eds. Fedna Bonacich, Lucie Cheng, Norma Chinchilla, Vorma Hamilton, and Paul Ong. Philadelphia, Pa: Iemple University.

Buchanan. Jannes, Robert l'ollison, and Gordon Iullock, eds. 1980). Tou atd a Thery of the Rent-Seckng Sititt. College Station: T'exas A\& M University Press.

Cumings, Bnuce. 1998. "The Korean Crisis and the Bnt of Late Development." New Left Rerien 231: 43-72.

Deyo, Fred. 1(x)5. "Capital, Labor, and the State in Thai Industrial Restructuring: The Impact of Global Economic Transformations." In A New: World Order! Gibhal Tranformation in

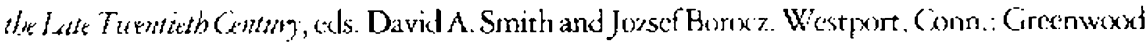
Press.

Dicken, Peter. 1992. Glabal Shift: The Internationalizatimn of Exomomi Acritity. Ind ed. New York: Guilford Publications.

Elson. Diane. 1989. "Bound By One Thread: The Restructuring of D. K. Clothing and Textile. Multinationals." In Instability and Change in the World Crimtry, eds. A. Mackwan and W.K. Tabb. New York: Monthly Review Press.

Evans. Peter. 19)5. Embedded Autonomy: States and Inthustral Trangformation. Princeton, N.J.: Princeton University Press.

Feuntes and Ehrenreich. 1984. Women in the Gluksl Foutom. Boston. Mass.: South End Press. Frobel, F. J. Heinrichs and O. Kreye. 1981. The New Intemationat Ditisom of Labur. Cambridge: Cambridge University.

Gereffi, Giany. 19x) 2. "New Realities of Industrial Development in East Asia and! Latin America:

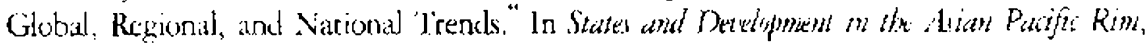
eds. Richard Appelbaum and Jeffrey Henderson. Newhury Park. Calif:: Sage.

1994. "The Organization of Buyer-Driven Gkobal Commoxtity Chains: How L.S. Retailers Shape Overseas Production Networks." In Commdity Chaini and Global Capitalim, eds. G. Gereffi and M. Korzenicwicz. Westpon, Cem.: Greenwoud Press. 
Gereffi, Gary and Donald Wyman, eds. 19\%0. Mknufatmmng Mirules: Paths of Industrialization in Intin Ameriat and Fast Asia. Princeton, N.J.: Princeton Liniversity Press.

Gerlach, Michael L. 1992. Alliance Capitalism: The Secial Organization of Japanese Business. Berkeley: Universicy of Califomia Press.

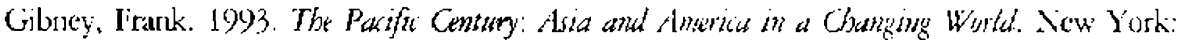
Charles Scribner's Sons.

Gold, Thomas. 1986. State and Soxiety in the Taiuan Mrrale. Armonk, N.Y.: M.E. Sharpe. Johnson, Chalmers. 1982. MTI and the Jatanese Miracte. Stanford, Calif: Stanford Unversity Press.

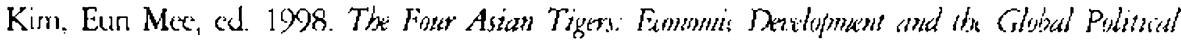
Finnmm: San Diego, Calif.: Academic Press.

Krueger, Anne. 197/4. "The Political Economy of the Rent-Secking Society:" Amerian Eimmmi Reriti: (44 (3): 29) 1-303.

Kin, Tran H. 1991. Eommon of Vietram: Rezieus and Statistic. ldanoi: Statistical Publishing House.

Lee, Su-Hown. 1998. "Crisis in Korea and the IMF Control." In Th' Friur Arian Tigurs: Ecomomic Let elopment and the Gilobal Political Eonom;, ed. Eun Mee Kin. San Diego, Calif.: Academic Press.

Lui, Tai-lok. 1998. "Trust and Chinese Business Behavior, Hong Kong: Ixpartment of Sx iokgy, Chinese Liniversity of Hong Kong." (unpublished paper)

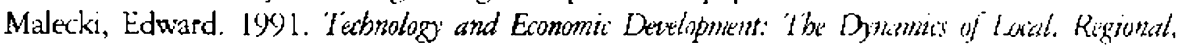
and National Change. New York: Longman.

McCormick, Barrett. 1998. "Political Change in China and Vienam: Coping with the Consequences of Economic Reforms." The China fommal 40): 121-43.

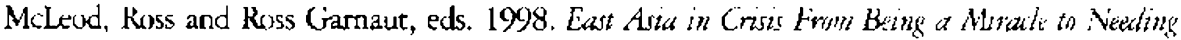
One? New York: Routledge.

Orru, Marco, Nicole Woolsey Biggart, and Gary G. lamilen. 1992. "Organizational Isomorphism in East Asia: Broadening the New lnstitutionalism." In The Nenc Institutionalism in Onganizational Anabssis, edited by Walter W. Powell and Paul J. DiMaggio. Chicago: Lniversity of Chicago Press.

Piore. Michatel J. and Charles F. Sabel. 1984. The Sectond Indesirial Divide: Prossibilities for Prosperity. New York: Basic Books.

Porter, Michael E. 1990. Th' Competitue Adrantagk of Nations. New York: The Free Press.

Pye, Lucian. 1985. Sijian Poutr and Polisics: The Caltwal Dimensoms of Aatborit). Cambridge, Masss.: Relknap Press.

Redding, S. Conrdon. 1990. The Spirit of Chinese Capitalism. New York: Walter de Gruyter.

Scott, Alen. 1988. "Flexible Production Systems and Regional Development." Intemational Journal of Urban and Regional Research Vol. 12: 171-86.

Smith. David A 19)6. "Going South: Global Restructuring and Garmenc Production is Three East Asian (ases." Arian Perspettine 20) (2): ?11.11.

. 1999. "Lessons of Global Neo-Liberalism?'The East Asian Economic Crisis Reconsidered." Ginhal Ennmic Reziene. 27 (4): $45-63$.

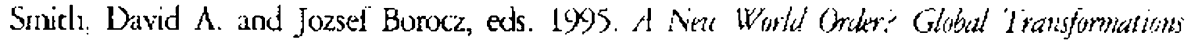
in the late Tukntieth Centuig: Westport, Conn: Cirecrwood.

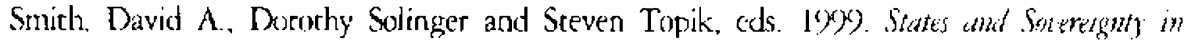
the Glybal komom. London, UK: Routledge.

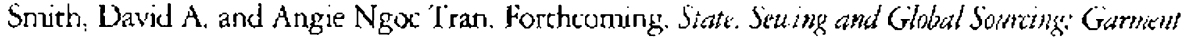
Pratuation in lietnums teronome Iransition. Now York: Rowman and Littlefield. 
Itan, Angie Nyoc. 1997. "Through the Lye of the Needle: Vietramese Textile and Garment Indust ries Rejoining rhe Global Counery." Crossmads: An Interdisciplinum foumd of Snutberst Alizan Studies 10 (2): 83-126.

1999. "Global Subcontracting and Women Workers in Comparative Perspective."

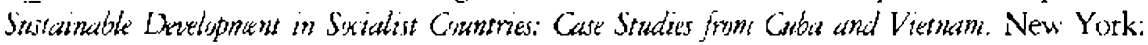
Macmillan Publishers.

Tran, Angir. Ngox and David A. Smith. 1999. "Cautious Reforners and Fence- Breakers: Vietnam's Economic Transition in Comparative Perspective." Humbolds Jaurnad of Social Relations 24 (2): $51-100$.

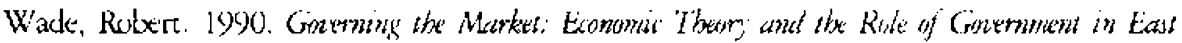
Agian Indsitrializatiom. Princcton: Princecon University Press.

Wade. Robert and Frank Veneroso. 1998. "The Crathering World Slump and rhe Barte over Capital Controls." Ner' Left Review 231: 12-42.

Whitely, Richard. 140)2. Biwmess Systems in East Asia: Rimis. Harkets. and Socteties. Newbury Park, Calif.: Sagc.

19)6. "Business Systems and Gilobal Comnodity Chains: Compet ing or Complenzentary Forms of Economic Organizacion." Competition and Change: 'Tht Inumal of Glabal Business and Political Econmm I (4) (fall): 411-25.

World Bank. 1993. The East Asian Mirade: Econumic Gimath and Public Poligy. New York: Oxtord Universicy Press.

1997. World Dateloment Repnot 1997: The Stat in a Changing World. New York: Oxford Universicy Press. 